\title{
Prevalence of Korean cats with natural feline coronavirus infections
}

\author{
Dong-Jun An ${ }^{1}$, Hye-Young Jeoung ${ }^{1}$, WooSeog Jeong ${ }^{1}$, Jee-Yong Park' ${ }^{1}$ Myoung-Heon Lee ${ }^{1}$ and Bong-Kyun Park ${ }^{2^{*}}$
}

\begin{abstract}
Background: Feline coronavirus is comprised of two pathogenic biotypes consisting of feline infectious peritonitis virus (FIPV) and feline enteric coronavirus (FECV), which are both divided into two serotypes. To examine the prevalence of Korean cats infected with feline coronavirus (FCoV) type I and II, fecal samples were obtained from 212 cats (107 pet and 105 feral) in 2009.

Results: Fourteen cats were FCoV-positive, including infections with type I FCoV $(n=8)$, type II FCoV $(n=4)$, and types I and II co-infection $(n=2)$. Low seroprevalences $(13.7 \%, 29 / 212)$ of FCoV were identified in chronically ill cats $(19.3 \%, 16 / 83)$ and healthy cats $(10.1 \%, 13 / 129)$.

Conclusions: Although the prevalence of FCoV infection was not high in comparison to other countries, there was a higher prevalence of type I FCoV in Korean felines. The prevalence of FCoV antigen and antibody in Korean cats are expected to gradually increase due to the rising numbers of stray and companion cats.
\end{abstract}

Keywords: FCoV I, FCoV II, Seroprevalence

\section{Background}

Feline coronavirus (FCoV) is an enveloped, positivesense, single-stranded RNA virus of the family Coronavirideae within the order Nidovirales. FCoVs are comprised of two pathogenic biotypes [1] consisting of feline infectious peritonitis virus (FIPV) and feline enteric coronavirus (FECV), which are both divided into two serotypes (Type I and II). The serotypes differ in their growth characteristics in cell culture and antigenicity, relative to canine coronaviruses (CCoVs) [2].

The prevalence of type I and II FCoV have been surveyed in many countries, including Japan [3], United States [4], United Kingdom [5], Austria [6], Switzerland [7], and Taiwan [8]. The majority of field isolates in these countries are of type I, regardless of the assay method [4].

FCoVs are associated with mild or subclinical enteric infections [9]. However, in a small proportion of cats, FCoV infection leads to the development of a lethal, immune-mediated condition known as feline infectious peritonitis (FIP) [10,11]. FIP is a complex immune

\footnotetext{
* Correspondence: parkx026@snu.ac.kr

${ }^{2}$ Department of Veterinary Medicine Virology Lab, College of Veterinary

Medicine, Seoul National University, Seoul, 151-742, Korea

Full list of author information is available at the end of the article
}

disease involving virus or viral antigen, antiviral antibodies, and complement. Cats that do not develop antiFCoV antibodies do not develop FIP.

Serological surveys of FCoV infection have involved detection of antibody by indirect fluorescent antibody assay (IFA) or enzyme-linked immunosorbent assay (ELISA) [12-15]. A plaque-reduction neutralization test (PRNT) was developed to serologically distinguish FCoV type I and II infections in cats [16].

In a previous study, the number of cats raised in Seoul, the capital city of South Korea, was reported to be around 30,000 in 2004 [17]. The most common breed in Korea is the Korean short hair cat, but this has been changing the recent years due to the increasing number of cats that are being raised as companion cats. Previously, there have been case reports of FIP in a Persian chinchilla (2 years age, female) and a Korean short hair cat (3 months age, male) [18], but no nationwide survey for FCoV has been carried out in Korea.

Therefore, the objectives of the current study were to identify the seroprevalence of $\mathrm{FCoV}$ and to classify the $\mathrm{FCoV}$ serotypes in Korean cats in comparison with prevalence in other countries.
C Biomed Central

(c) 2011 An et al; licensee BioMed Central Ltd. This is an Open Access article distributed under the terms of the Creative Commons Attribution License (http://creativecommons.org/licenses/by/2.0), which permits unrestricted use, distribution, and reproduction in any medium, provided the original work is properly cited. 


\section{Methods}

\section{Cat specimens}

Feline serum and fecal swab samples were collected from 212 cats consisting of 107 samples from six local animal hospitals (four in Seoul and two in Kyunggi) and 105 samples from two animal shelters (Incheon and Daejeon) in 2009. Of the 212 samples, 129 were from clinically healthy cats and 83 were from cats displaying symptoms of illness that included inappetence, anorexia, weight loss, lethargy, icterus, fever, diarrhea, and thoracic effusion.

\section{RNA extraction and reverse transcription-polymerase chain reaction ( $R T-P C R$ )}

Viral RNA was extracted from fecal samples using TRIzol LS ${ }^{\text {b }}$ (Invitrogen, Valencia, CA) according to the manufacturer's instructions. Two RT-PCR methods were used: one enabled the highly sensitive detection in fecal samples and the other distinguished type I from type II. The former method was based on nested PCR using primers for the amplification of the highly conserved 3'-untranslated region (3'-UTR) of the FCoV genome [19]. The latter method [8], which was based on the spike gene region of the FCoV genome, is a multiplex-nested PCR using $2 \mu \mathrm{L}$ of the first PCR product as the template and nested primers [5] for discrimination of Type I and II FCoVs. In addition, FCoV positive samples were further tested for feline panleukopenia virus (FPLV) using a specific FPLB primer set and conditions previously described [20] to identify possible relationships between the two viruses.

\section{IFA detection of anti-FCoV antibody}

Anti-FCoV antibody titers in feline serum samples were determined by IFA using porcine kidney-15 (PK-15) cells and porcine transmissible gastroenteritis virus (TGEV) [19]. In brief, PK-15 cells were inoculated with TGEV at a multiplicity of infection of 10 plaque forming units (PFU)/cell and incubated for $8 \mathrm{~h}$ at $37^{\circ} \mathrm{C}$. PK-15 cells were trypsinized, mixed approximately half-andhalf with uninfected cells, and seeded into wells of eight-well glass plates (Nutacon, Amsterdam, The Netherlands). Cells were incubated for $60 \mathrm{~min}$ at $37^{\circ} \mathrm{C}$ with serial two-fold dilutions of serum samples in phosphate buffered saline (PBS), washed three times for 5 minutes, and incubated for 1 hour with fluorescein isothiocyanate-conjugated goat anti-feline immunoglobulin G (KPL, Gaithersburg, MD).

\section{Phylogenetic analysis}

Korean FCoV sequences from this study and 30 sequences from global FCoV isolates obtained from GenBank were aligned using the Clustal X 1.83 sequence alignment program [21]. Nucleotide and amino acid sequence identities among the Korean FCoV isolates were calculated using BIOEDIT 7.053 [22]. The phylogenetic tree was created by a neighbor-joining method using MEGA 4.0 software [23].

\section{Results}

The total number of positive fecal samples for FCoV 14 cats, which were mostly Korean short hair breeds over one year of age. Of these FCoV positive cats, three were identified to be co-infected with FPLV (Table 1).

Among the 212 feline fecal swab samples, eight were positive for FCoV type I, four were positive for type II, and two were positive for types I and II (Table 2). Eleven of the positive samples were from cats displaying symptoms of infection. Three of the positive samples were from asymptomatic cats (Table 2 ). Among the ill cats, the infections were due to type I $(n=6)$, type II $(n=3)$ and both types I and II $(n=$ 2). Of the three positive samples from asymptomatic cats, two were type I and one was type II (Table 2). Of the 107 specimens collected from six local animal hospitals, the nine FCoV-infected cats included type I $(\mathrm{n}=5)$, type II $(\mathrm{n}=2)$, and types I and II $(\mathrm{n}=2)$ (Table 1). The 105 fecal swab samples obtained from two animal shelters included five that were FCoV positive (three type I and two type II; co-infection was not evident).

Alternatively, canine coronavirus (CCoV) or TGEV can be used as a target antigen because of their close serological identity with FCoV. The prevalence of antiFCoV antibody in the feline samples was low (29/212; $13.7 \%)$ and comprised 20-fold $(\mathrm{n}=5), 40$-fold $(\mathrm{n}=6)$, 80 -fold $(\mathrm{n}=5), 160$-fold $(\mathrm{n}=3), 320$-fold $(\mathrm{n}=2), 640$ fold $(\mathrm{n}=4), 1280$-fold $(\mathrm{n}=3)$, and 2560-fold $(\mathrm{n}=1)$ (Figure 1). The 29 cats having FCoV antibodies included 16 of the 83 ill cats (19.3\%) and 13 of the 129 healthy cats $(10.1 \%)$, and, according the location of sample collection, represented animal hospital cats $(14.0 \%, 15 / 107)$ and shelter cats $(13.3 \%, 14 / 105)$.

A phylogentic analysis was performed using spike gene partial sequences from $46 \mathrm{CoVs}$ including Korean FCoV from the current study ( $\mathrm{n}=16)$, FCoVs obtained globally $(\mathrm{n}=23), \mathrm{CCoVs}(\mathrm{n}=5)$, raccoon $\operatorname{dog} \mathrm{CoV}$ (RDCoV; $\mathrm{n}=1$ ), and Chinese fetter badger CoV (CFBCoV; $\mathrm{n}=1$ ). The phylogenetic tree data set was resampled 1000 times to generate bootstrap percentage values. The phylogenic tree clearly delineated types I and II FCoVs. The analysis showed that of the ten Korean FCoVs in the type I group, nine type I FCoVs belonged to a different lineage when compared to strains isolated from other parts of the world, and only the Korean FCoV 08K-1991 was grouped with UCD1 (Japan). All six Korean type II FCoVs (08K-609, 08K656, 08K-1154, 08K-1553, 08K-559/II and 08K-1429/II) 
Table 1 Summary for 14 cats with Feline Coronavirus type I, and II, or co-infection

\begin{tabular}{|c|c|c|c|c|c|c|c|c|c|c|c|}
\hline $\begin{array}{l}\text { Cat } \\
\text { No }\end{array}$ & Breed & Gender & $\begin{array}{c}\text { Age } \\
\text { (month) }\end{array}$ & Region & $\begin{array}{l}\text { Collection } \\
\text { Site }\end{array}$ & $\begin{array}{l}\text { Collection } \\
\text { Month }\end{array}$ & $\begin{array}{l}\text { FCoVs } \\
\text { type }\end{array}$ & Strain & $\begin{array}{c}\text { Accession } \\
\text { No }\end{array}$ & $\begin{array}{l}\text { Antibody titer } \\
\text { (IFA) }\end{array}$ & FPLV \\
\hline 420 & $\begin{array}{c}\text { Domestic short } \\
\text { hair }\end{array}$ & $M$ & 12 & Kyonggi & Hospital & April & I & $08 K-420$ & JN654401 & 80 & - \\
\hline 478 & $\begin{array}{c}\text { Domestic short } \\
\text { hair }\end{array}$ & M & 9 & Seoul & Hospital & April & । & $08 K-478$ & JN654402 & 640 & - \\
\hline 559 & $\begin{array}{c}\text { Domestic short } \\
\text { hair }\end{array}$ & M & 30 & Kyonggi & Hospital & April & | \& || & $\begin{array}{c}08 K-559 / \\
\text { । } \\
08 K-559 / \\
\|\end{array}$ & $\begin{array}{l}\text { JN654403 } \\
\text { JN654411 }\end{array}$ & 160 & - \\
\hline 609 & $\begin{array}{c}\text { Domestic short } \\
\text { hair }\end{array}$ & $\mathrm{F}$ & 14 & Seoul & Hospital & May & $\|$ & 08K-609 & JN654412 & 20 & - \\
\hline 656 & Scottish Fold & $\mathrm{F}$ & 12 & Daejeon & Shelter & May & $\|$ & 08K-656 & JN654413 & 640 & - \\
\hline 958 & $\begin{array}{c}\text { Domestic short } \\
\text { hair }\end{array}$ & M & 12 & Incheon & Shelter & June & । & 08K-958 & JN654404 & 40 & - \\
\hline 1011 & Scottish Fold & M & 42 & Seoul & Hospital & June & I & 08K-1011 & JN654405 & 20 & + \\
\hline 1154 & $\begin{array}{c}\text { Domestic short } \\
\text { hair }\end{array}$ & $\mathrm{F}$ & 11 & Daejeon & Shelter & July & $\|$ & 08K-1154 & JN654414 & 80 & - \\
\hline 1177 & Perisan & M & 14 & Kyonggi & Hospital & July & । & 08K-1177 & JN654406 & 320 & - \\
\hline 1429 & Scottish Fold & $\mathrm{F}$ & 15 & Seoul & Hospital & Aug & | \& || & $\begin{array}{c}08 K- \\
1429 / 1 \\
08 K- \\
1429 / I I\end{array}$ & $\begin{array}{l}\text { JN654407 } \\
\text { JN654415 }\end{array}$ & 80 & - \\
\hline 1549 & $\begin{array}{c}\text { Domestic short } \\
\text { hair }\end{array}$ & M & 10 & Incheon & Shelter & Sep & । & 08K-1549 & JN654408 & 640 & - \\
\hline 1552 & $\begin{array}{l}\text { Domestic short } \\
\text { hair }\end{array}$ & M & 12 & Seoul & Hospital & Sep & I & 08K-1552 & JN654409 & 20 & + \\
\hline 1553 & $\begin{array}{l}\text { Domestic short } \\
\text { hair }\end{array}$ & $\mathrm{F}$ & 24 & Seoul & Hospital & Sep & $\|$ & 08K-1553 & JN654416 & 160 & - \\
\hline 1991 & $\begin{array}{l}\text { Domestic short } \\
\text { hair }\end{array}$ & M & 24 & Incheon & Shelter & Dec & I & 08K-1991 & JN654410 & 80 & + \\
\hline
\end{tabular}

was shown to be originated from the same lineage as F20-54-II isolated from Japan (Figure 2).

\section{Discussion}

The prevalence of type I and II FCoVs has been surveyed in many countries [3-8,16]. Similar to these other countries, the majority of FCoV infections in Korea was shown to be of type I (66.7\%), with type II constituting approximately $33.3 \%$. The type I virus is more genetically diverse than type II, perhaps reflecting its global

Table 2 Prevalence of feline CoV in Korea by type and clinical status.

\begin{tabular}{|c|c|c|c|c|}
\hline \multirow{3}{*}{$\begin{array}{l}\text { Clinical } \\
\text { status }\end{array}$} & \multicolumn{4}{|c|}{ Number of case tests } \\
\hline & \multicolumn{3}{|c|}{ Typable } & \multirow[t]{2}{*}{ Total } \\
\hline & Type I & Type II & $\begin{array}{c}\text { Type I and } \\
\text { II }\end{array}$ & \\
\hline III & $6 / 83(7.2 \%)$ & $3 / 83(3.6 \%)$ & $2 / 83(3.6 \%)$ & $\begin{array}{r}11 / 83 \\
(13.5 \%)\end{array}$ \\
\hline Healthy & $\begin{array}{l}2 / 129 \\
(1.6 \%)\end{array}$ & $\begin{array}{l}1 / 129 \\
(0.8 \%)\end{array}$ & 0/129 (0\%) & $3 / 129(2.3 \%)$ \\
\hline Total & $\begin{array}{l}8 / 212 \\
(3.8 \%)\end{array}$ & $\begin{array}{l}4 / 212 \\
(1.9 \%)\end{array}$ & $2 / 212(0.9 \%)$ & $\begin{array}{r}14 / 212 \\
(6.6 \%)\end{array}$ \\
\hline
\end{tabular}

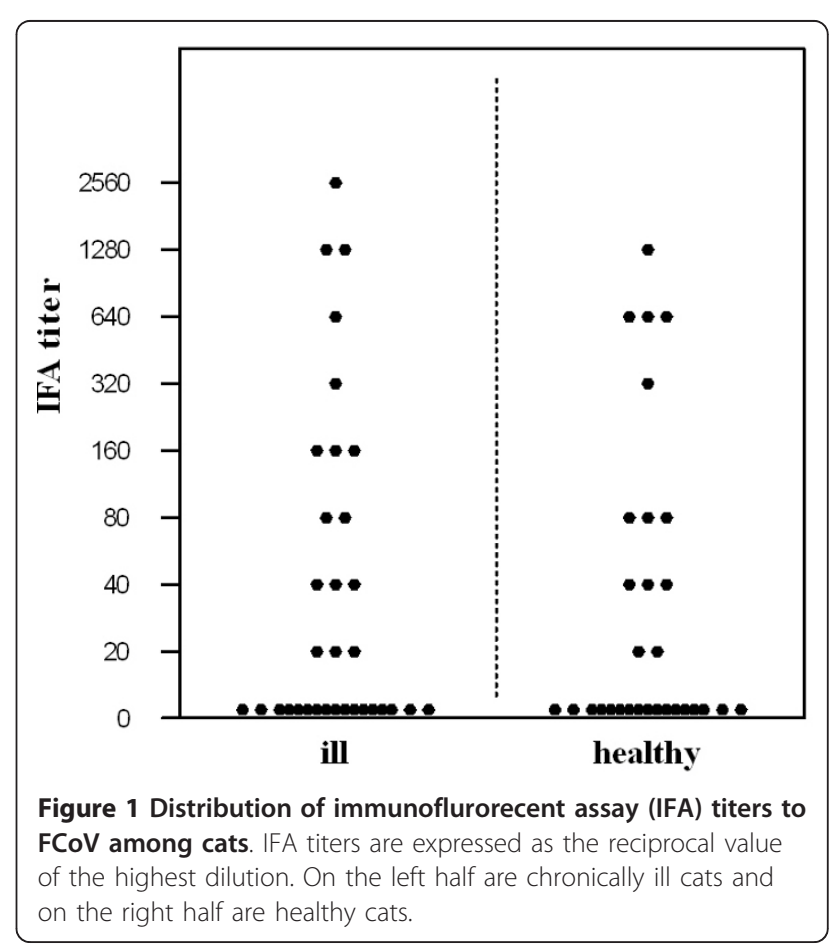




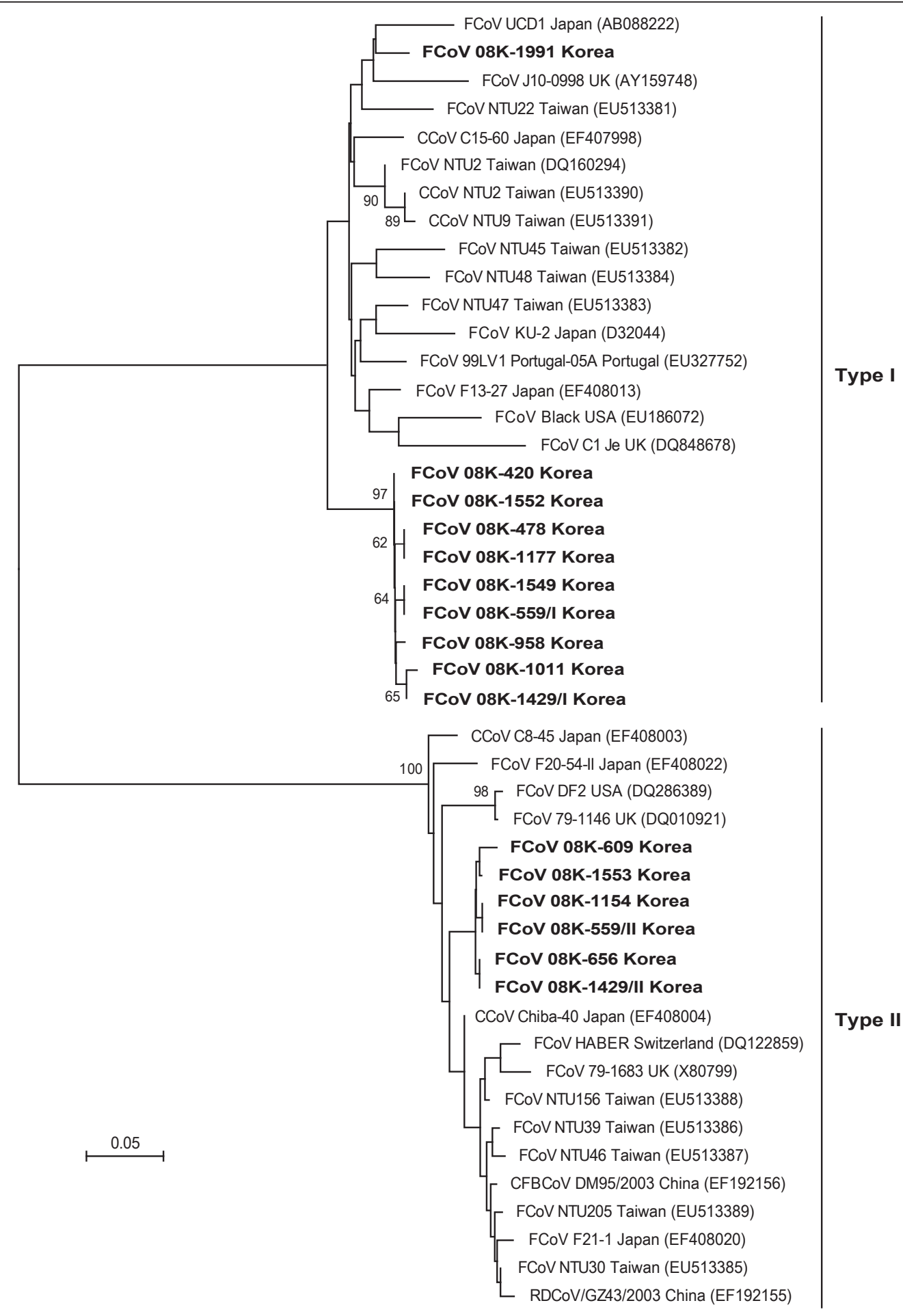

Figure 2 Phylogenetic relationships between partial spike gene sequences of $\mathbf{4 6}$ coronaviruses. The samples were comprised of 16 FCoVs from Korea, 23 FCoVs from around the world, five CCoVs, one RDCoV, and one CFBCoV. All sequences except the 16 FCoV sequences derived from the current study (in boldface) were obtained from GenBank. An unrooted phylogenetic tree was constructed from aligned sequences by the neighbor-joining (NJ) method using MEGA 4.0 software. Bootstrap percentages are shown above those branches that are supported in at least $60 \%$ of the 1,000 replicates. Scale bar indicates nucleotide substitutions per site. 
distribution and a long period of persistence of the virus in asymptomatic cats [5,24].

Previous studies have reported the proportion of infected cats that are co-infected with type I and II viruses were as high as $15.8 \%(6 / 38)$ in Taiwan [8] and $6.8 \%(5 / 74)$ in Austria [6]. In the current study, there was no incidence of co-infection with type I and II $\mathrm{FCoV}$ in healthy cats, whereas the prevalence of coinfection in ill Korean cats was somewhat higher (14.3\%, 2/14) than that reported in cats from Austria. Investigation of both of the co-infected Korean cats revealed that they dwelled in a house that also had a dog as a companion animal. This indicates that type II FCoV may have originated from a double recombination between type I FCoV and type II CCoV [25].

Previous research conducted in several countries has revealed that $69-91 \%$ of seropositive cats are suspected of having a type I infection $[3,4,7]$. In the present study, although the evaluation for seroprevalence by the virus neutralization test between types I and II FCoV could be not performed, FCoV seroprevalence was presently somewhat lower than the previously reported prevalences from other countries.

In a study conducted in Japan in the early 1990s, a low prevalence of FCoV antibodies was detected in chronically diseased cats $(21.3 \%)$ and non-diseased cats (13.4\%) by IFA [3]. A more recent study in that country that utilized PRNT reported a substantially greater (three times) seroprevalence [16]. The latter authors suggested that, despite the differing analysis regimens and samples, type II FCoV infection has been decreasing in Japanese domestic cats in recent years. Accordingly, we anticipate that the use of the PRNT array for Korean feline specimens would produce a higher seroprevalence than was evident using IFA.

Phylogenic analysis of the spike gene of FCoV types I and II clearly discriminated between the two types (Figure 2), in agreement with previous results [8]. The 16 Korean FCoVs in our study were classified into two serotypes, type I $(\mathrm{n}=10)$ and II $(\mathrm{n}=6)$ on the neighbor joining tree which was inferred using the Kimura 2 parameter model assuming uniform rates of change among sites. Geographical origin or sub-lineage classification of the FCoVs was not evident due to low nodal support value, but the perfect bootstrap percentage on the node $(\mathrm{CCoV} \mathrm{C} 8-45)$ indicates that our strains may have originated from this type II prototype.

In this study, we examined the prevalence of Korean cats infected with type I and II FCoV and identified the seroprevalence of FCoV in Korean cats. Type I and II FCoV are not highly prevalent in comparison to the prevalence of other countries. However, in recent years
Korean feline population, has been rising and it's possible their occurrence may increase in the future.

\section{Acknowledgements}

We are grateful to Ms Hyun-Jung Kim for technical assistance.

\section{Author details}

${ }^{1}$ National Veterinary Research and Quarantine Service, Anyang, Kyunggi-do, 430-824. Korea. ${ }^{2}$ Department of Veterinary Medicine Virology Lab, College of Veterinary Medicine, Seoul National University, Seoul, 151-742, Korea.

\section{Authors' contributions}

DJA: design of the experiments and writing the manuscript, JYP: help in writing the manuscript, WJ and MHL: conducted data analysis, HYJ: conducted PCR for FCoV, BKP: final correction of the manuscript. All authors read and approved the final manuscript.

\section{Competing interests}

The authors declare that they have no competing interests.

Received: 26 January 2011 Accepted: 28 September 2011 Published: 28 September 2011

\section{References}

1. Pedersen NC: An overview of feline enteric coronavirus and infectious peritonitis virus infections. Feline Pract 1987, 23:7-22.

2. Pedersen NC, Black JW, Boyle JF, Evermann JF, McKeirnan AJ, Ott RL: Pathogenic differences between various feline coronavirus isolates. Adv Exp Med Biol 1984, 173:365-380.

3. Hohdatsu T, Okada S, Ishizuka Y, Yamada H, Koyama H: The prevalence of types I and II feline coronavirus infections in cats. J Vet Med Sci 1992, 54:557-562.

4. Vennema $\mathrm{H}$ : Genetic drift and genetic shift during feline coronavirus evolution. Vet Microbiol 1999, 69:139-141.

5. Addie DD, Schaap IA, Nicolson L, Jarrett O: Persistence and transmission of natural type I feline coronavirus infection. I Gen Virol 2003, 84:2735-2744.

6. Benetka V, Kubber-Heiss A, Kolodziejek J, Nowotny N, Hofmann-Parisot M, Mostl K: Prevalence of feline coronavirus types I and II in cats with histopathologically verified feline infectious peritonitis. Vet Microbiol 2004, 99:31-42.

7. Kummrow M, Meli ML, Haessig M, Goenczi E, Poland A, Pedersen NC, Hofmann-Lehmann R, Lutz H: Feline coronavirus serotypes 1 and 2: seroprevalence and association with disease in Switzerland. Clin Diagn Lab Immunol 2005, 12:1209-1215.

8. Lin CN, Su BL, Wanga CH, Hsieh MW, Chueh TJ, Chueh LL: Genetic diversity and correlation with feline infectious peritonitis of feline coronavirus type I and II: A 5-year study in Taiwan. Vet Microbiol 2009, 136:233-239.

9. Pedersen NC, Boyle JF, Floyd K, Fudge A, Barker J: An enteric coronavirus infection of cats and its relationship to feline infectious peritonitis. Am J Vet Res 1981, 42:368-377.

10. Poland AM, Vennema H, Foley JE, Pedersen NC: Two related strains of feline infectious peritonitis virus isolated from immunocompromised cats infected with a feline enteric coronavirus. J Clin Microbiol 1996, 34:3180-3184.

11. Vennema H, Poland A, Foley J, Pedersen NC: Feline infectious peritonitis viruses arise by mutation from endemic feline enteric coronaviruses. Virology 1998, 243:150-157.

12. Horzinek MC, Osterhaus ADME: Feline infectious peritonitis: a worldwide serosurvey. Am J Vet Res 1979, 40:1487-1492.

13. Ishida T, Washizu T, Fukuoka J, Toriyabe K, Uchino T, Motoyoshi S: Feline infectious peritonitis virus antibody test using enzyme-linked immunosorbent assay. J Vet Med Sci 1987, 49:145-149.

14. Pedersen NC: Serologic studies of naturally occurring feline infectious peritonitis. Am J Vet Res 1976, 37:1449-1453.

15. Scott FW: FIP antibody test-interpretation and recommendations. J Am Vet Med Assoc 1979, 175:1164-1168. 
16. Shiba N, Maeda K, Kato H, Mochizuki M, Iwata H: Differentiation of feline coronavirus type I and II infections by virus neutralization test. Vet Microbiol 2007, 124:348-352.

17. Myung BY, Kim SE, Shim KM, Ryu JW, Kim SH, Moon C, Bae CS, Choi SH, Kang SS, Park H: Clinical characteristics of oral diseases on stray cats in Gwangju. Korean J Vet Res 2010, 50:303-310.

18. Kim TS, Lee SH, Lim SJ, Park HJ, Song ES, Jung DW, Kim DH, Song KH: Application of thromboxane synthetase inhibitor (Ozagrel $\mathrm{HCL}$ ) in feline infectious peritonitis. Korean J Vet Res 2010, 50:63-69.

19. Herrewegh AA, de Groot RJ, Cepica A, Egberink HF, Horzinek MC, Rottier PJ: Detection of feline coronavirus RNA in feces, tissues, and body fluids of naturally infected cats by reverse transcriptase PCR. J Clin Microbiol 1995, 33:684-689.

20. An DJ, Jeong W, Jeoung HY, Yoon SH, Kim HJ, Park JY, Park BK: Phylogenetic analysis of feline panleukopenia virus (FPLV) strains in Korean cats. Res Vet Sci 2011, 90:163-167.

21. Thompson JD, Gibson TJ, Plewniak F, Jeanmougin F, Higgins DG: The CLUSTAL_X windows interface: flexible strategies for multiple sequence alignment aided by quality analysis tools. Nucleic Acids Res 1997, 25:4876-4882

22. Hall TA: BIOEDIT: a user-friendly biological sequence alignment editor and analysis program for windows 95/98/NT. Nucleic Acids Symp Ser 1999, 41:95-98.

23. Tamura K, Dudley J, Nei M, Kumar S: MEGA4: Molecular Evolutionary Genetics Analysis (MEGA) software version 4.0. Mol Biol Evol 2007, 24:1596-1599.

24. Herrewegh AA, Mähler M, Hedrich HJ, Haagmans BL, Egberink HF, Horzinek MC, Rottier PJ, de Groot RJ: Persistence and evolution of feline coronavirus in a closed cat-breeding colony. Virology 1997, 234:349-363.

25. Herrewegh AA, Smeenk I, Horzinek MC, Rottier PJ, de Groot RJ: Feline coronavirus type II strains 79-1683 and 79-1146 originate from a double recombination between feline coronavirus type I and canine coronavirus. J Virol 1998, 72:4508-4514.

doi:10.1186/1743-422X-8-455

Cite this article as: An et al:: Prevalence of Korean cats with natural

feline coronavirus infections. Virology Journal 2011 8:455.

\section{Submit your next manuscript to BioMed Central} and take full advantage of:

- Convenient online submission

- Thorough peer review

- No space constraints or color figure charges

- Immediate publication on acceptance

- Inclusion in PubMed, CAS, Scopus and Google Scholar

- Research which is freely available for redistribution

Submit your manuscript at www.biomedcentral.com/submit
Biomed Central 